\title{
Economical Investigation of the Feasibility of Utilizing the PV Solar Lighting for Jordanian Streets
}

\author{
Lina Al-Kurdi ${ }^{a, *}$, Reem Al-Masri $^{a}$, A. Al-Salaymeh ${ }^{b}$ \\ ${ }^{a}$ Mechanical Engineering Department, The University of Jordan, Amman 11942, Jordan \\ ${ }^{b}$ Energy, Water and Environment Center, The University of Jordan, Amman 11942, Jordan
}

\begin{abstract}
Jordan blessed with a various type of renewable energy resources, being located on the Sun Belt is the most perspicacious and substantial matter. In spite of these facts the energy problem is one of the most frustrating challenges facing Jordan these days, causing tremendous pressure on the country's economy, obviously the solution lies in reducing the proportion of the imported fuel for the benefit of exploitation of renewable energy sources. Street lighting is a vital sector in any country growth. This vital sector represents $2 \%$ of annual electricity consumption in Jordan. This paper will introduce feasibility study for the installation photovoltaic cells in street lighting for existing and futuristic project as a step toward solving the problem facing this sector. The study shows that photovoltaic is feasible for futuristic due to minimizing the work frame time and the cost required for the infrastructure.
\end{abstract}

Keywords: Renewable Energy, Photovoltaic, PV, Street Lighting, Solar Energy.

\section{Introduction}

Due to the increase in electricity demand worldwide it is becoming more common for cities to cut their power consumption through self-generation from renewable energy sources such as solar and wind to produce electricity. Jordan imports $97 \%$ of its energy from neighbor countries despite the fact that it is blessed with great amounts of renewable energy resources especially that it lies in the sun built. Solar irradiance in Jordan is one of the heights worldwide; Figure 1) represents global irradiation at optimum angle in Jordan. The total direct annual solar radiation ranges from $2400 \mathrm{kWh} / \mathrm{m} 2$ to more than $2700 \mathrm{kWh} / \mathrm{m} 2$, with average hour of light $2007.5 \mathrm{hr}$ per year [2]. These high solar energy amounts encourage capital investments in solar energy systems in Jordan. According to the comprehensive strategy for energy sector, renewable is targeted to reach $10 \%$ of total energy mix by 2020 , compromising $15-20 \%$ of consumed electricity [1]. The PV energy price, government utilization and legislation are factors that increase public motivation toward utilizing and developing PV systems.
The key to reach this target share of renewable energy is to encourage public participation in the implementation of renewable energy as it is evident from the examples of leading countries in renewable energy; the government has to take a leading role in utilizing renewable energy into sectors that touch the bases of daily life. Street lighting sector is a vital sector in any country's growth. This vital sector represents $2 \%$ of annual electricity consumption in Jordan.

The government showed an interest in reducing the energy consumption of the street lighting sector through many management decisions that recently has been, such as, reducing the number of lightened fixtures in selected streets around the country which had a direct impact on public satisfaction, wellbeing and on the number of accidents. Figure (2) shows the number of accidents in selected roads for the past three years. It is evident that the road safety decreased since implementation in 2012 by $50 \%$ for the first half of 2013 [4].

Photovoltaic systems may support the government management strategy without affecting streets safety; these systems have been commercially available for quite some time. The cost of photovoltaic has dropped significantly over the past few years due to technology improvement and increase in demand.

${ }^{*}$ Corresponding author. Tel.: +962779990879

E-mail: linam.kurdi@yahoo.com

(C) 2015 International Association for Sharing Knowledge and Sustainability

DOI: $10.5383 /$ ijtee.10.01.012 


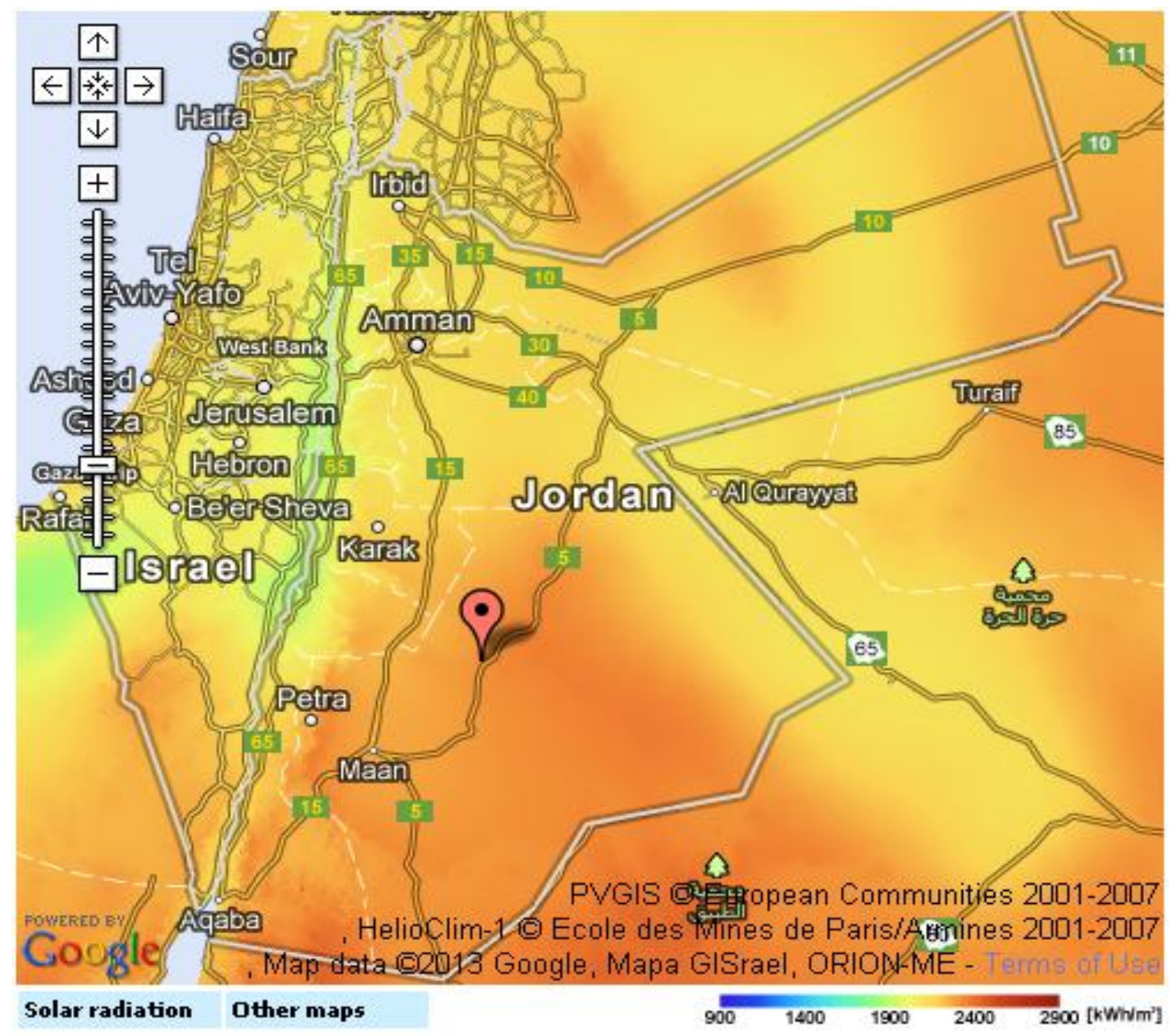

Figure 1: Global irradiation at optimum angle in Jordan [3]

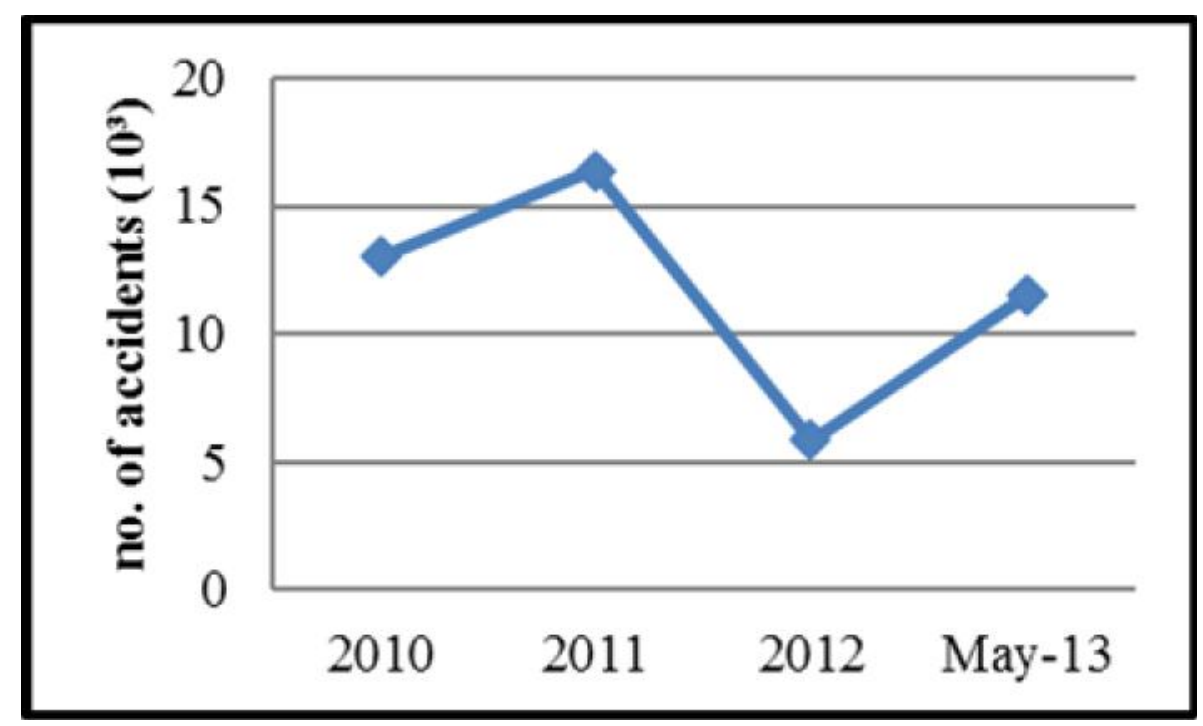

Figure 2: The number of traffic accidents in the last three years in Jordan [4]. 
This study aims to give an alternative option in street lighting in Jordan by introducing a comparison between solar powered LED street lighting for new road project and existing ones, in addition to determining the feasibility of these projects. The economic feasibility of the solar powered roadway lighting using LED luminaries $110 \mathrm{~W}$ for $2 \mathrm{~km}$ Naur highway is studied; the highest solar irradiation is $8.31 \mathrm{kWh} / \mathrm{m}^{2} /$ day and average maximum ambient temperature is $32^{\circ} \mathrm{C}$ while the average minimum temperature is $14^{\circ} \mathrm{C}$. Figure (3) shows the monthly solar irradiation for Naur highway.

\section{Literature Review}

A comparative analysis on economics of street lighting powered by public electricity utility and solar energy in Nigeria was carried out by (Tsado and Ganiyu, 2012) [5]; the result showed that, the initial cost of installing solar energy for standalone street lighting is $\mathrm{N} 6,402 / \mathrm{hr}$ which is more expensive than using public electricity utility with a cost of $\mathrm{N} 2,508.9 / \mathrm{h}$. However, over a period of 20 years such projects become feasible. The feasibility emphasizes the need to supplement and eventually replace the existing conventional street lighting powered by electricity from public utility.

Recently many studies had been made on the feasibility of introducing photovoltaic to the lighting sector. $\mathrm{Wu}$, etal. (2009) [6] investigated the design of the solarpowered LED roadway lighting using high-power LED luminaries $(100 \mathrm{~W})$ and estimated the installation cost for a $10 \mathrm{~km}$ highway with 2 lanes. This solar-powered LED roadway lighting system can save $75 \%$ lighting energy as compared to the mercury lamp. The payback time for the excess investment of the whole lighting system is 3.3 years for high-power LED using solarpowered.

Rizaho, China is a solar powered city. In addition to $99 \%$ of households in the central district, most of traffic signals and street lights are powered by photovoltaic. The achievement was the result of an unusual convergence of three key factors: a supportive government policy, local solar industries that seized the opportunity, and strong political will among the city's leadership. In addition, government buildings and homes of city leaders were the first to have the panels installed [7].

In 2003, ten solar powered grid tied street lamps in south Wales, UK mainland where designed and installed by SolarGen Solutions. Excess power generated by the system is sold back for use by other customers. The annual energy supplied to the grid and the consumed energy were monitored. The objective of the project was to compare the consumption saving with the predicted $35 \%$ increase in electricity cost. It was found that street lighting projects are cost effective investment in securing tomorrow's energy at today's prices as well as going a long way to offsetting the effect of global warming [8].

\section{Description of solar powered LED lighting fixture}

A stand-alone design was advised by ministry of housing and public works which applies to the required specifications of the standard high pressure sodium street lighting design main specification are presented in table (1). The solar panel unit is a monocrystalline solar panel which has the advantage of better efficiency in low light conditions.

\section{Economic analysis of LED and solar powered LED}

The present paper studied the economic feasibility of the solar powered street lighting using LED luminaires for $2 \mathrm{~km}$ highway $40 \mathrm{~m}$ apart. Tables (2) presents an economic comparison for three kinds of street lighting projects, namely, solar power LED for existing projects, solar powered LED for new projects and conventional high pressure sodium street lighting projects is carried out. Each unit of solar powered LED street lighting system includes a two $300 \mathrm{Wp} \mathrm{PV}$ modules, four $100 \mathrm{Ah}-12 \mathrm{~V}$ batteries, and two 110W LED lighting fixture.

Table (2) shows that the installation cost is 134.250 thousand JOD for LED lighting powered by grid and 126.200 thousand JOD for solar-powered. The total installation cost of high pressure sodium grid-powered street lighting is 110.250 thousand JOD. The excess cost of LED mainly comes from the cost of LED lamp and solar PV. But, the cost of electrical power generation and electrical transmission components can be greatly reduced since more than $50 \%$ of energy was saved using LED. Table (3) shows that the payback period for the excess investment of LED is 7.2 years for LED using grid power and 3.15 years for LED using solar power. This result shows the solar-powered roadway LED lighting is economically feasible for new road projects.

Table (1): Solar street lighting specifications

\begin{tabular}{ll}
\hline Description & \multicolumn{1}{l}{ value } \\
Minimum luminous at mid line of the street & 18 lux \\
Lamp efficacy $[\mathrm{lm} / \mathrm{W}]$ & 72 \\
Lighting power per lamp $[\mathrm{W}]$ & 110 \\
Operating temperature of the lamp $\left[{ }^{\circ} \mathrm{C}\right]$ & $-20-50$ \\
Power of one solar panel $[\mathrm{W}]$ & 250 \\
Pole hight $[\mathrm{m}]$ & 12 \\
No. of heads on each pole & 2
\end{tabular}




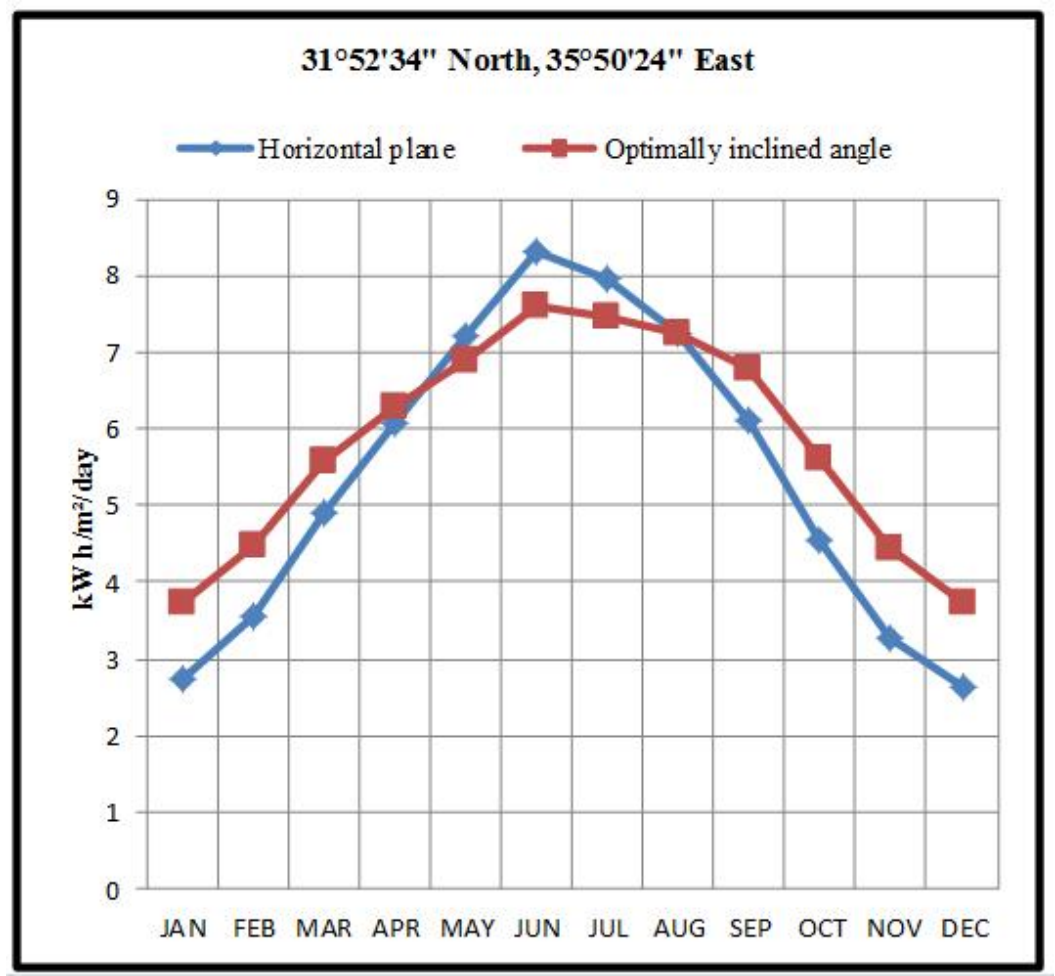

Figure 3: Monthly solar irradiation in Naur Highway Street [3]

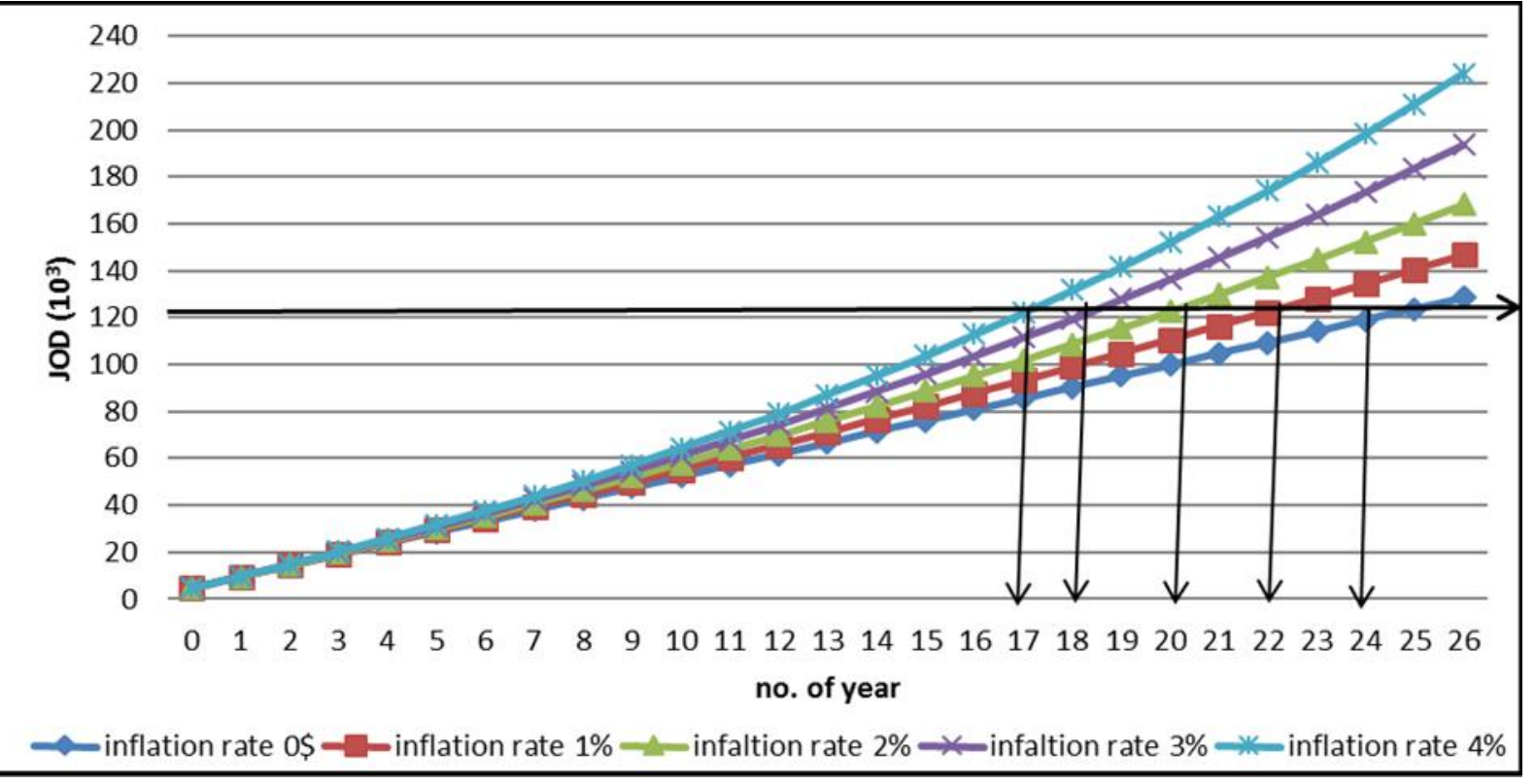

Figure 4: Accumulated saved costs as a result of installing stand-alone PV systems as a function of years for different values of inflation rate in electricity prices. 
Table (2): Naur street lighting installation cost

\begin{tabular}{|c|c|c|c|c|c|c|}
\hline Road way distance & $2 \mathrm{~km}$ & & & & & \\
\hline No. of lamps installed & 40m apart, & lamps & & & & \\
\hline \multirow{2}{*}{ Type of lighting design } & \multicolumn{2}{|c|}{$\begin{array}{l}\text { Grid-powered High Pressure } \\
\text { Sodium (18 LUX) }\end{array}$} & \multicolumn{2}{|c|}{ Grid-powered LED (18 LUX) } & \multicolumn{2}{|c|}{ Solar-powered LED (18 LUX) } \\
\hline & Unit Price, JOD & Subtotal & Unit Price, JOD & Subtotal & Unit Price, JOD & Subtotal \\
\hline Lamp cost, JOD & 70 & 3,500 & 620 & 31,000 & 620 & 31,000 \\
\hline Photocell cost, JOD & & 50 & & 50 & - & \\
\hline Power line cost, JOD & & 30,000 & & 30,000 & & 25 \\
\hline PVC pipe cost, JOD & & 40,000 & & 40,000 & & 25 \\
\hline Pole cost, JOD & 450 & 22,500 & 450 & 22,500 & 600 & 30,000 \\
\hline 3 phase distribution board cost, JOD & & 1,200 & & 1,200 & - & \\
\hline Grounding rod cost, JOD & & 500 & & 500 & - & \\
\hline Flexible cable cost, JOD & & 1,000 & & 1,000 & - & \\
\hline Total solar PV module cost, JOD & - & & - & & 378 & 18,900 \\
\hline Total battery cost, JOD & - & & - & & 660 & 33,000 \\
\hline Controller Cost, JOD & - & & - & & 105 & 5250 \\
\hline Civil construction cost, JOD & - & 8,000 & - & 8,000 & & 8,000 \\
\hline \multicolumn{7}{|l|}{ Fright, JOD } \\
\hline Total Installation Cost, JOD (\$US) & & $\begin{array}{c}110,250 \\
(155,874.53)\end{array}$ & & $\begin{array}{c}134,250 \\
(189,806.40)\end{array}$ & & $\begin{array}{c}126,200 \\
(178,425.09)\end{array}$ \\
\hline
\end{tabular}

(1\$US is $0.7073 J O D, 2013)$

Table (3): Naur street economic analysis for new road projects

\begin{tabular}{|c|c|c|c|}
\hline Road way distance, $\mathrm{km}$ & $2 \mathrm{~km}$ & & \\
\hline No. of installed lamps & $40 \mathrm{~m}$ apart, 50 & & \\
\hline \multirow{2}{*}{ Type of lighting design } & Grid-powered H.P.S & Grid-powered LED & Solar-powered LED \\
\hline & (18 LUX) & (18 LUX) & (18 LUX) \\
\hline Lighting power per lamp, $\mathrm{W}$ & 250 & 110 & 110 \\
\hline Total power consumption, $\mathrm{kW}$ & 12.5 & 5.5 & 5.5 \\
\hline Total installation cost, JOD & 110,250 & 134,250 & 126,200 \\
\hline \multicolumn{4}{|l|}{ Maintenance and lamp replacement } \\
\hline Maintenance cost, JOD/yr & (3\%) $3,307.5$ & $(1.5 \%) 2,014$ & $(1.5 \%) 1893$ \\
\hline Lamp replacement time per year & 6 & 14 & 14 \\
\hline Battery replacement cost, JOD/yr & 0 & 0 & 66 (included) \\
\hline Maintenance, JOD/yr & $3,307.5$ & 2,014 & 1893 \\
\hline \multicolumn{4}{|l|}{ Economic analysis } \\
\hline Power saving, $\mathrm{kW}$ & Base & 7 & 12.5 \\
\hline Lighting hours, hr/day & 10 & & \\
\hline Electricity fixed price in Jordan, JOD/kWh & 0.08 & & \\
\hline Yearly energy savings, $\mathrm{kWh} / \mathrm{yr}$ & Base & 25550 & 45,625 \\
\hline Yearly energy savings, JOD (\$US)/yr & Base & $2,044(2,889.86)$ & $3,650(5.160 .47)$ \\
\hline Maintenance savings, JOD (\$US)/yr & Base & $1,293(1,828.08)$ & $1,414.5(1,999.86)$ \\
\hline Additional investment, JOD (\$US) & Base & $24,000(33,931.87)$ & $15,950(22,550.56)$ \\
\hline Payback period, yr & Base & 7.2 & 3.15 \\
\hline
\end{tabular}


Table (4) shows that the payback period for the excess investment on existing road projects of LED is 6.76 years for LED using grid power and 24.92 years for LED using solar power. This result shows the solar-powered roadway LED lighting is not economically feasible for existing road projects.

Figure (4) shows a Solar Powered LED system for existing Roads. The payback period of this system which is about 26 years in case of zero inflation rate in the cost of the grid electricity over the life time of photovoltaic system.
Applying the same inflation rates to the increase in the price of grid electricity and maintenance cost, leads to a reduction in the payback period to 24 years, 22 years, 20 years, 18 years and 17 years for the inflation rates of 1 to $4 \%$ consequently.

Taking into account the continuous increase in fossil fuels prices and the decrease in photovoltaic technology prices, Photovoltaic will be a viable futuristic alternative.

Table (4): Naur street economic analysis for existing road projects

\begin{tabular}{|c|c|c|c|}
\hline Road way distance, $\mathrm{km}$ & $2 \mathrm{~km}$ & & \\
\hline No. of installed lamps & $40 \mathrm{~m}$ apart, 50 & & \\
\hline \multirow{2}{*}{ Type of lighting design } & Grid-powered H.P.S & Grid-powered LED & Solar-powered LED \\
\hline & (18 LUX) & (18 LUX) & (18 LUX) \\
\hline Lighting power per lamp, W & 250 & 110 & 110 \\
\hline Total power consumption, $\mathrm{kW}$ & 12.5 & 5.5 & 5.5 \\
\hline Total installation cost, JOD & 110,250 & 31,000 & 126,200 \\
\hline \multicolumn{4}{|l|}{ Maintenance and lamp replacement } \\
\hline Maintenance cost, JOD/yr & $(3 \%) 3,307.5$ & $(2.5 \%) 762$ & $(1.5 \%) 1,893$ \\
\hline Time replacement time per year & 6 & 14 & 14 \\
\hline Battery replacement cost, JOD/yr & 0 & 0 & 66 (included) \\
\hline Maintenance, JOD/yr & $3,307.5$ & 762 & 1,893 \\
\hline \multicolumn{4}{|l|}{ Economic analysis } \\
\hline Power saving, kW & Base & 7 & 12.5 \\
\hline Lighting hours, hr/day & 10 & & \\
\hline Electricity fixed price in Jordan, JOD/kWh & 0.08 & & \\
\hline Yearly energy savings, $\mathrm{kWh} / \mathrm{yr}$ & Base & 25,550 & 45,625 \\
\hline Yearly energy savings, JOD (\$US)/yr & Base & $2,044(2,889.86)$ & $3,650(5,160.47)$ \\
\hline Maintenance savings, JOD (\$US)/yr & Base & $2,545.5(3,598.90)$ & $1,414.5(1,999.86)$ \\
\hline Additional investment, JOD (\$US) & Base & $31,000(43,828.67)$ & $126,200(178,425.09)$ \\
\hline Payback period, yr & Base & 6.76 & 24.92 \\
\hline
\end{tabular}

(1\$US is $0.7073 \mathrm{JOD}, 2013$ ) 


\section{Conclusion}

Photovoltaic systems have been commercially available for quite some time. The present study investigated the feasibility of the solar-powered LED street lighting using LED luminaire $100 \mathrm{~W}$.

This solar-powered LED street lighting system can save 50\% of lighting energy as compared to the high pressurized sodium lamp.

The payback period for the additional investment of new road projects lighting system is 7.2 years for grid powered LED and 3.15 years for solar powered LED and ranges from 6.76 to 24.92 years for existing road projects. Therefore, the solar powered LED lighting system is economically feasible in considering the payback time and the lifetime for new road projects.

\section{Acknowledgments}

The authors wish to thank the Ministry of Housing and Public Works and the Great Amman Municipality for their support.

Also, the following privet companies for their corporation in this study:

- Super Solar for Energy and Engineering,

- Philadelphia Solar

- Shamsi Alsateah for Alternative Energy Solutions.

\section{References}

[1] Ministry of Energy and Mineral Resources, "Annual Report", 2011. Haik, Y: Engineering Design Process. Pacific Grove: Brooks/Cole, 2003.

[2] Al-Salaymeh A., Al-Hamamre Z., Sharaf F. and Abdelkader M.R. (2010), “Technical and economical assessment of the utilization of photovoltaic systems in residential buildings: The case of Jordan", Energy Conversion and Management 51, 1719-1726

[3] http://re.jrc.ec.europa.eu/pvgis/apps4/pvest.php?map $=$ africa\&lang=en\#

[4] Public security Diractrate - command and control center (2013).

[5] Tsado J. and Ganiyu M.A. (2012), "Engineering economics of solar based street lighting in Nigeria", Journal of economics and engineering, 3(1), 13-16.

[6] Wu M.S., Huang H.H., Huang B.J., Tang C.W. and Cheng C.W.(2009), "Economic feasibility of solarpowered led roadway lighting", Renewable Energy, 34, 1934-1938.

[7] Xuemei B. (2007), "RIZHAO, CHINA: SolarPowered City", World Watch, 20(2), 31

[8] Power Engineer (2003), Page:7.

[9] Ministry of Public Works and Housing Jordan

[10] Great Amman Municipality. 